\title{
Peranan Pembelajaran Pendidikan Pancasila dan Kewarganegaraan Terhadap Karakter Kejujuran Peserta Didik di SMK PGRI Sukoharjo
}

\author{
Oktaviana Dita Prasticha ${ }^{1}$, Annisah Rahmawati ${ }^{2}$, Dias Yanalesta ${ }^{3}$, Ika Murtiningsih ${ }^{4}$ \\ ${ }^{1234}$ PPKn, Universitas Veteran Bangun Nusantara Sukoharjo \\ Email: ${ }^{1}$ oktavianadita6@ gmail.com, ${ }^{2}$ annisah2808@ gmail.com, \\ ${ }^{3}$ diasyanalesta11@gmail.com, ${ }^{4}$ ika.murtyy@gmail.com
}

\begin{abstract}
Abstarct
This study aims to describe the role of Civics learning on the character of honesty students at SMK PGRI Sukoharjo. This research belongs to descriptive qualitative research. The research subjects were students of class XI Motorcycle Engineering and Business (TBSM). This research was conducted with the method of observation to the students of SMK PGRI. Research done at the time of Civics learning takes place. The results of the research are the students to be honest in the exams and the final assessment of the semester, students answer honestly the questions given by the teacher, the students promised not to lie, and students with honestly admit if it is can not doing homework. Civics learning a very important role in the formation of the character of honesty students, in learning, there are moral values both of which can be emulated by the students. Moral values contained in the material values of pancasila which became the material for the students of class X. The character of honesty students at SMK PGRI very visible at the time of learning in class and the behavior of the students outside the classroom.
\end{abstract}

\section{Keywords: Civics Learning, Honesty, Role}

\begin{abstract}
Abstrak
Penelitian ini bertujuan untuk mendeskripsikan peranan pembelajaran PPKn terhadap karakter kejujuran peserta didik di SMK PGRI Sukoharjo. Penelitian ini termasuk penelitian kualitatif deskriptif. Pengumpulan data pada penelitian ini bersumber dari pengamatan atau observasi. Subyek penelitian adalah peserta didik kelas XI Teknik dan Bisnis Sepeda Motor (TBSM). Penelitian ini dilakukan dengan metode observasi terhadap peserta didik SMK PGRI. Penelitian dilakukan pada saat pembelajaran PPKn berlangsung. Hasil dari penelitian yaitu peserta didik jujur dalam mengerjakan ulangan maupun penilaian akhir semester, peserta didik menjawab jujur pertanyaan yang diberikan guru, peserta didik berjanji untuk tidak berbohong, dan peserta didik dengan jujur mengakui jika tidak bisa mengerjakan pekerjaan rumah. Pembelajaran PPKn sangat berperan dalam pembentukan karakter kejujuran peserta didik, dalam pembelajaran terdapat nilainilai moral baik yang bisa dicontoh oleh peserta didik. Nilai moral tersebut terdapat dalam materi Nilai Pancasila yang menjadi materi untuk peserta didik kelas X. Karakter kejujuran peserta didik di SMK PGRI sangat terlihat pada saat pembelajaran dikelas maupun tingkah laku peserta didik diluar kelas.
\end{abstract}

Kata kunci: Pembelajaran PPKn, Kejujuran, Peranan

\section{Pendahuluan}

Pendidikan Pancasila dan Kewarganegaraan (PPKn) adalah komponen yang penting dalam sebuah pembelajaran di sekolah, baik sekolah formal maupun yang informal. Hal demikian dapat kita lihat dari keberadaan mata pelajaran PPKn di berbagai 
jenjang pendidikan baik dari Sekolah Dasar (SD), sekolah Menengah Pertama (SMP). Sekolah Menengah Atas (SMA) ataupun di perguruan tinggi. Sesuai bunyi pembukaan Undang-Undang Dasar 1945 "mencerdaskan kehidupan bangsa" yang merupakan citacita bangsa Indonesia adalah salah satu pendorong bahwa Pendidikan Pancasila dan Kewarganegaraan sangatlah penting di suatu pembelajaran.

Pendidikan karakter pada dasarnya hampir sama dengan pendidikan akhlak mulia bagi peserta didik. Pendidikan karakter melibatkan aspek pengetahuan atau cognitive, perasaan atau feeling, tindakan atau action, dan sosial. Empat aspek tersebut yang dapat menguatkan karakter anak di dalam menjalankan kehidupan. Peserta didik hendaknya diarahkan dalam pengembangan bidang kecerdasan yaitu kecerdasan intelektual, spiritual, sosial dan emosional. Melalui kecerdasan empat ranah tersebut nantinya penyelengaraan pendidikan Indonesia dapat dilaksanakan dan dijalankan dengan baik.

Pengembangan dan perkembangan pendidikan nasional di Indonesia dapat dilihat dari munculnya 18 aspek karakter yang harus ada dalam pengembangan karakter bangsa dan pendidikan budaya yang di buat oleh Kementerian Pendidikan. Dimulai pada tahun ajaran 2011/2012, pada seluruh tingkatan pendidikan di Indonesia diharapkan harus menyisipkan pendidikan karakter tersebut dalam proses pembelajaran. Menurut pusat kurikulum dalam Samani dan Haryanto (2011:52), 18 karakter terdiri dari: religius, jujur, toleransi, disiplin, kerja keras, kreatif, mandiri, demokratis, rasa ingin tahu, semangat kebangsaan, cinta tanah air, menghargai prestasi, bersahabat atau komunikatif, cinta damai, gemar membaca, peduli lingkungan, peduli sosial, dan tanggung jawab.

Jujur merupakan salah satu dari 18 aspek karakter yang harus ada dalam pengembangan karakter bangsa dan pendidikan budaya, dengan demikian peserta didik diharapkan memiliki kejujuran dalam bersikap. Guna menumbuhkan karakter tersebut kementerian pendidikan menyisipkannya dalam pembelajaran disetiap jenjang. Dalam Pendidikan Pancasila Dan Kewarganegaraan (PPKn) pendidikan karakter kejujuran tersebut telah diajarkan kepada peserta didik, hal tersebut dapat dilihat dalam pembelajaran nilai-nilai pancasila dan nilai moral yang menjadi materi pembelajaran PPKn. Kejujuran bagi peserta didik sangatlah penting terlebih lagi sebagai bekal dalam dunia bekerja.

Demi mendapatkan hasil intelektual yang baik peserta didik sering melakukan hal-hal yang melanggar norma-norma dan tidak mencerminkan karakter yang baik seperti mencontek saat ulangan, melihat handphone pada saat ujian, membayar teman untuk membuat tugas, joki-joki tes, plagiat dan lain sebagainya. Kualitas generasi muda seperti yang telah disebutkan diatas tentu saja dapat mengancam keberlangsungan hidup bangsa Indonesia, hal ini ditambah dengan persoalan-persoalan seperti banyaknya pengangguran, kesenjangan sosial, kemiskinan, adanya korupsi dan lainnya yang dapat memecah belah bangsa ini dengan mudah. Hal-hal tersebut juga menjadi alasan Pemerintah untuk menyisipkan pendidikan karakter yang baik guna membentuknya menjadi karakter yang dimiliki peserta didik baik dari jenjang SD, SMP, SMA, maupun perguruan tinggi. Karakter kejujuran sangatlah penting dimiliki oleh peserta didik, karena dengan bekal kejujuran peserta didik akan secara terbiasa menerapkannya di dunia kerja nantinya. Permasalahan karakter kejujuran peserta didik sangatlah penting untuk masa depan peserta didik, sehingga perlu adanya usaha untuk menumbuhkannya sejak dini dengan upaya tersebut pembelajaran PPKn bisa saja memiliki peran dalam menumbuhkan sikap kejujuran peserta didik.

Berdasarkan latar belakang diatas, dirumuskanlah masalah dalam penelitian ini sebagai berikut. "Bagaimanakah peranan pembelajaran PPKn terhadap sikap kejujuran peserta didik SMK PGRI Sukoharjo?”. Penelitian ini memiliki tujuan untuk 
mendeskripsikan peranan pembelajaran PPKn terhadap karakter kejujuran peserta didik di SMK PGRI Sukoharjo. SMK PGRI Sukoharjo dipilih sebagai tempat dilakukannya penelitian ini karena dianggap sebagai sekolah yang tepat untuk menguji kejujuran peserta didik, sekolah ini menghasilkan lulusan-lulusan yang berkualitas dan mampu langsung bekerja sesuai jurusannya. Penulis juga melakukan Program Asistensi Mengajar disekolah ini sehingga banyak kemudahan yang bisa didapat pada saat penelitian.

\section{Kajian Pustaka}

\section{Pembelajaran PPKn}

\section{a. Pengertian pembelajaran PPKn}

Pembelajaran merupakan kegiatan interaksi yang terjadi antara peserta didik dengan guru dan sumber belajar yang dilakukan disuatu lingkungan belajar, sebuah proses dimana seseorang turut serta dalam tingkah laku tertentu. Pembelajaran adalah salah satu bagian dari pendidikan. Corey (1986:195). Menurut Soemantry (dalam Baswan, 2013:263) Pendidikan Pancasila dan Kewarganegaraan (PPKn) adalah merupakan pengetahuan yang bertujuan menjadikan warga negara dengan baik. Sedangkan PPKn adalah pendidikan kewarganegaraan, yaitu suatu pendidikan yang melibatkan status formal warga Negara.

Pembelajaran PPKn adalah salah satu pelajaran utama di sekolah yang memiliki tujuan dalam pengembangan kecerdasan warga negara dalam bidang sosial, spiritual, rasional dan emosional guna mengembangkan tanggung jawab peserta didik yang juga sebagai warga negara, serta mengembangkan peserta didik supaya bisa berpartisipasi secara aktif sebagai warga negara yang baik. Menurut Udin S. Winataputra, dkk (2007: 52) Dalam pembelajaran PPKn, persyaratan utama yang harus dimiliki seorang guru adalah kemampuannya dalam menguasai metode pembelajaran yang akan dipakai.

Dari beberapa pendapat diatas dapat disimpulkan pembelajaran PPKn adalah interaksi yang terjadi antara peserta didik dan guru mengenai PPKn yang terjadi dalam lingkungan belajar yang bertujuan menjadikan peserta didik menjadi warga negara yang baik, dan diharapkan dapat mengembangkan kecerdasan sosial, spiritual, emosional sebagai warga Negara yang baik.

\section{b. Tujuan pembelajaran PPKn}

Tujuan pembelajaran PPKn secara umum adalah untuk mendukung keberhasilan tujuan pendidikan nasional sesuai dalam penjelasan UU No 20 Tahun 2003 pasal 37 yang berisi: pendidikan kewarganegaraan dimaksudkan untuk membentuk peserta didik menjadi manusia yang memiliki rasa kebangsaan dan cinta tanah air.

Menurut Winarno (2005:29) Tujuan yang diharapkan dari Pendidikan Pancasila dan Kewarganegaraan adalah peserta didik menjadi warga negara yang baik dan cerdas, yakni warga negara yang memiliki rasa peka tinggi, cepat tanggap, sikap kritis, dan kreativitas sosial dalam menjalankan kehidupan bermasyarakat secara tertib, kreatif, inovatif dan damai. 
Tujuan PPKn adalah untuk membentuk karakter warga negara yang baik. Sedangkan tujuan mata pelajaran PPKn, menurut Mulyasa yang dikutip oleh Baswan (2013:264) adalah untuk menjadikan peserta didik :

1. Dapat berpikir kritis dan rasional.

2. Berpartisipasi aktif serta bertanggung jawab, dan

3. Berkembang secara positif dan demokratis.

Sesuai dengan uraian diatas tujuan pembelajaran PPKn adalah peserta didik diharapkan menjadi warga Negara yang cerdas dengan kreativitas sosial dalam berkehidupan bermasyarakat, bernegara dan berbangsa, memiliki rasa kebangsaan dan cinta tanah air.

\section{c. Komponen pembelajaran PPKn}

Berdasarkan pendapat Winarno pembelajaran PPKn (2005:29) harus mencakup 3 komponen yaitu pengetahuan kewarganegaraan (civic knowledge), keterampilan kewarganegaraan (civic skill) dan civic watak kewarganegaraan (civic disposition).

a. Komponen pertama dalam pembelajaran PPKn adalah pengetahuan kewarganegaraan (civic knowledge) mengenai kemampuan akademik keilmuan mengenai teori atau konsep politik, hukum dan moral.

b. Komponen kedua yakni keterampilan kewarganegaraan (civic skill) komponen ini terdiri dari keterampilan intelektual dan keterampilan berpartisipasi dalam kehidupan berbangsa dan bernegara.

c. Komponen pembelajaran PPKn yang ketiga watak kewarganegaraan (civic disposition), komponen watak merupakan komponen yang paling penting. Komponen watak bisa disebut hasil akhir dari komponen sebelumnya, hal ini karena adanya penekanan dalam bagian watak, karakter, sikap dan potensi lain yang bersifat efektif.

\section{Sikap Kejujuran}

\section{a. Pengertian Kejujuran}

Kesuma, dkk (2012 : 16) menyatakan bahwa jujur adalah suatu keputusan yang dibuat seseorang guna mengungkapkan perasaan, baik katakata atau perilakunya yang sesuai realitas yang ada tanpa memanipulasi dengan bohong atau menipu untuk memperoleh keuntungan untuk dirinya sendiri. Definisi jujur ini sangatlah erat hubungannya dengan kebaikan (kemaslahatan). Kebaikan sendiri memiliki arti bawa kita lebih mengutamakan kepentingan orang lain dibanding dengan kepentingan diri kita sendiri.

Mustari (2011: 13-15) menyatakan sikap jujur merupakan sebuah perilaku yang memiliki dasar pada upaya untuk menjadikan diri sendiri sebagai orang yang dapat dipercaya dalam perkataan, tindakannya, dan pekerjaannya, baik terhadap diri sendiri maupun pihak yang lain. Jujur adalah suatu sikap moral yang memiliki sifat yang positif dan juga mulia, seperti penuh dengan kesabaran dan lurus, sekaligus tidak bohong atau pun curang.

Kesuma, dkk (2012:16) juga menyatakan bahwa kejujuran sangatlah penting dilakukan penerapannya di sekolah hal ini sebagai pembentukan karakter anak-anak indonesia pada masa saat ini. Karakter kejujuran ini dapat dilihat melalui tingkah laku peserta didik pada saat dikelas, misalnya saja saat peserta didik sedang melakukan ujian atau ulangan harian apakah mereka akan lebih condong melakukan perbuatan menyontek sehingga peserta didik ini 
tidak berbuat jujur dan telah menipu diri sendiri, teman, orang tua, dan gurunya dengan telah memanipulasi nilai yang telah didapat yang bukanlah hasil kerja kerasnya sendiri melainkan hasil dari mencontek dari orang lain. Zuriah (2008: 49) mengungkapkan bahwa nilai dan juga prinsip sebuah kejujuran dapat ditumbuhkan pada peserta didik di setiap jenjang pendidikan, hal ini dapat dilakukan dengan kegiatan mengoreksi hasil ulangan harian secara silang dalam kelas. Guru dapat mengoreksi ulang pekerjaan peserta didik satu per satu setelah peserta didik mengoreksinya, kegiatan ini bertujuan untuk melatih kejujuran dan tanggung jawab peserta didik.

Dari pendapat tersebut dapat disimpulkan bahwa kejujuran adalah sikap seseorang yang diungkapkan melalui perkataan atau perbuatan sesuai keadaan yang sebenarnya terjadi tanpa ada upaya memanipulasi, sehingga dirinya selalu dapat dipercaya oleh orang lain karena ucapan maupun tindakannya selalu bersifat benar dan sesuai dengan fakta dan kenyataan yang ada.

\section{b. Karakteristik Kejujuran}

Menurut dari Kesuma, dkk (2012:17) orang yang biasanya memiliki karakter jujur akan memiliki ciri perilaku sebagai berikut:

1. Jika bertekat (inisiasi keputusan) untuk melakukan sesuatu, tekatnya adalah kebenaran dan kebaikan.

2. Jika dia berkata bukan kebohongan (benar apa adanya)

3. Punya adanya kesamaan diantara yang dikatakan hatinya dengan apa yang dilakukan.

\section{Metode Penelitian}

Dalam meneliti peranan pembelajaran PPKn terhadap karakter kejujuran peserta didik, peneliti menerapkan penelitian kualitatif dan menggunakan pendekatan deskriptif. Pada sebuah penelitian, tentunya di dalamnya terdapat metode penelitian. Metode penelitian adalah alat untuk menyelesaikan permasalahan dalam sebuah penelitian yang dilakukan dengan terstruktur dan saksama untuk memperoleh fakta dan kesimpulan agar bisa menguasai, menerangkan, menduga, serta mengendalikan situasi (Ar Syamsuddin, 2006: 14). Metode penelitian berkenaan dengan prosedur yang diterapkan untuk memilih tempat, sumber data, data, sampel, validitas data, analisis, dan lain sebagainya (Santosa, 2017: 46).

Metode yang digunakan peneliti adalah metode kualitatif. Mahsun (2017:375) mengatakan bahwa metode kualitatif menitikberatkan pada penetapan arti, deskripsi, penyaringan, dan pencantuman data yang sesuai konteks dan lebih sering menjelaskan menggunakan kata-kata dibandingkan angka.

Instrumen penelitian merupakan sarana yang dipakai oleh peneliti dalam proses pengumpulan data. Hal ini supaya penelitiannya berjalan mudah dan mendapatkan hasil yang lebih baik, agar data yang diperoleh mudah diolah (Arikunto, 2010 : 203). Teknik merupakan cara yang lebih rinci yang digunakan dalam menjalankan suatu hal pada tahap-tahap penelitian tersebut.

Pengumpulan data pada penelitian ini bersumber dari pengamatan atau observasi yang dilakukan oleh peneliti sendiri, penelitian dilaksanakan dengan pengamatan terhadap peserta didik yang sedang mengerjakan tugas dan saat berlangsungnya pembelajaran. Subyek penelitian adalah kelas XI Teknik Dan Bisnis Sepeda Motor (TBSM) yang terdiri dari 32 peserta didik, obyek penelitian adalah peranan pembelajaran PPKn terhadap sikap kejujuran peserta didik dikelas. 


\section{Hasil dan Pembahasan}

Berdasarkan hasil observasi yang dilakukan oleh penulis kepada peserta didik di kelas Teknik Dan Bisnis Sepeda Motor (TBSM) yang terdiri dari 32 peserta didik dan dari materi observasi yang telah penulis susun dapat didiskripsikan bahwa:

1. Peserta didik memiliki karakter kejujuran dalam setiap pembelajaran, hal ini dapat dibuktikan dengan hasil observasi penulis bahwa setiap peserta didik mengerjakan ulangan harian dan Penilaian Akhir semester (PAS) dengan usahanya sendiri tanpa mencontek dari orang lain. Dari 32 peserta didik didapatkan hasil bahwa seluruh peserta didik tidak mencontek maupun mencari jawaban dari browsing. Dengan hasil yang demikian berarti bahwa pendidikan karakter yang terdapat dalam pembelajaran PPKn berperan penting dalam pembentukan karakter baik bagi peserta didik.

2. Pendidikan karakter peserta didik diperoleh melalui pembelajaran PPKn yang diterima peserta didik pada saat sekolah, karakter tersebut termasuk karakter kejujuran yang telah terlihat dimiliki peserta didik ketika observasi dilakukan.

3. Pada saat pembelajaran PPKn peserta didik juga terlihat memiliki karakter kejujuran dengan menjawab setiap pertanyaan yang diajukan pada saat pembelajaran dengan jujur, ada 5 peserta didik yang mengakui jika belum mengerjakan PR tanpa menutupi atau pun menyalin pekerjaan teman yang lain. Sedangkan peserta didik yang lainnya sudah mengerjakan PR tersebut.

Peserta didik mengerjakan ulangan secara jujur tanpa mencontek dari orang lain, nilai kejujuran ini dianggap sebagai nilai yang sangat penting untuk dimiliki seorang peserta didik hal ini karena kejujuran adalah pangkal kebaikan. Peserta didik yang jujur akan mampu mengendalikan sifat-sifat kurang baik seperti berbohong, berkhianat, dan mencontek. Peserta didik memiliki karakter kejujuran dalam setiap pembelajaran, hal ini dapat dibuktikan dengan hasil observasi penulis bahwa setiap peserta didik dari kelas XI TBSM yang berjumlah 32 semuanya mengerjakan ulangan harian dan Penilaian Akhir Semester dengan usahanya sendiri tanpa mencontek dari orang lain (teman).

Rasa percaya diri yang dimiliki seorang peserta didik sangat berkontribusi terhadap penurunan sikap perilaku mencontek peserta didik. Merasa yakin dengan kemampuan yang dimiliki dan pandangan positif terhadap keadaan diri dapat menciptakan rasa percaya diri yang tinggi. Berdasarkan hasil penelitian, peserta didik SMK PGRI mengerjakan ulangan dengan jujur tanpa mencontek hasil pekerjaan temannya. Setiap peserta didik mengerjakan ulangannya sendiri tanpa bantuan dari orang lain, tanpa membuka handphone (browsing), dan bertanya pada temannya. Sikap kejujuran yang tinggi ini didasari oleh rasa percaya diri yang dimiliki oleh peserta didik, sehingga peserta didik mampu dan tidak ragu mengerjakan ulangannya sendiri. Sikap kejujuran peserta didik ini harus diberi apresiasi, kejujuran dalam hal kecil pun harus diapresiasi agar peserta didik merasa bangga karena menerapkan kejujuran dalam hal kecil maupun besar. Dengan memberi apresiasi, diharapkan tingkat kejujuran di SMK PGRI Sukoharjo dapat meningkat setiap saat.

Peserta didik tidak mencontek saat Penilaian Akhir Semester (PAS), kejujuran memang menjadi syarat utama dalam menjalankan Penilaian Akhir Semester (PAS) Tidak ada keberhasilan yang didapat dari usaha yang dilakukan dengan cara yang tidak baik seperti mencontek dan berbuat kecurangan lainnya. Penilaian Akhir Semester di SMK PGRI Sukoharjo yang dimulai pada tanggal 27 November 2021 memperlihatkan bahwa para peserta didik kelas XI TBSM menerapkan sikap kejujuran saat mengerjakan Penilaian Akhir Semester (PAS), peserta didik dengan tenang mengerjakan soal yang ada dihadapan masing-masing tanpa bertanya atau mencontek jawaban dari orang lain (teman). 
Dengan diawasi oleh guru, peserta didik juga tidak dapat membuka handphone untuk mencari jawaban dari google ataupun bertukar jawaban dengan teman melalui WhatsApp. Para peserta didik sudah menyiapkan diri dengan baik untuk Penilaian Akhir Semester setiap harinya, oleh karena itu saat ujian dimulai para peserta didik dapat mengerjakan setiap soal dengan percaya diri dan dapat menyelesaikan soal ujian dengan kemampuannya sendiri.

Peserta didik menjawab secara jujur tentang pertanyaan yang diajukan saat pembelajaran, pada saat observasi berlangsung peserta didik diberikan pertanyaan tentang kegiatan sehari-hari selama kegiatan pembelajaran jarak jauh dan pertanyaan mengenai lebih nyaman pembelajaran jarak jauh atau tatap muka, peserta didik menjawab dengan jujur bahwa mereka lebih menyukai dan lebih mudah menerima materi pembelajaran jika melakukan tatap muka. Peserta didik juga menyampaikan bukti bahwa pembelajaran tatap muka lebih mudah untuk dimengerti dengan nilai tugas saat tatap muka yang lebih baik dibandingkan nilai tugas pembelajaran jarak jauh. Kejujuran peserta didik dalam menjawab pertanyaan dapat dinilai dengan cara bagaimana peserta didik menyampaikan jawaban dengan sangat yakin dan memberikan bukti bahwa jawabanya merupakan sebuah kejujuran.

Peserta didik berjanji untuk tidak berbohong kepada guru dan teman, sikap jujur sangat penting dalam kehidupan kita karena jujur adalah pondasi dalam perbuatan seharihari, sikap jujur harus ditanamkan dimana saja, baik di lingkungan masyarakat, keluarga maupun di sekolah. Sebagai seorang peserta didik, sikap jujur sangatlah penting, baik jujur terhadap guru maupun dengan teman di sekolah. Salah satu contoh penerapan sikap jujur ialah saat peserta didik melakukan cek suhu setiap datang ke sekolah, peserta didik menuliskan suhu dengan benar dan jujur di lembar absen yang telah di sediakan, hal yang sama juga di lakukan saat absen pulang.

Pembelajaran PPKn sangat berperan penting terhadap sikap jujur yang dimiliki setiap peserta didik, selain jujur dalam ulangan peserta didik di SMK PGRI juga jujur dalam setiap tingkah lakunya. Dalam percakapan biasa, kita bisa melihat bahwa peserta didik SMK PGRI menjawab dengan jujur setiap pertanyaan yang terlontar, hal ini karena setiap peserta didik merealisasikan apa yang mereka terima dalam pembelajaran PPKn. Dalam pembelajaran PPKn selalu diajarkan agar setiap peserta didik memiliki perilaku berbudi pekerti luhur, contohnya menghormati sesama teman di sekolah, guru dan siapapun yang ditemui di sekolah, saling membantu, bersikap adil, bijaksana, bertanggung jawab, disiplin, dan jujur.

Mengakui jika belum mengerjakan PR, beberapa kali masih ditemui peserta didik yang mengaku belum mengerjakan PR, namun 5 peserta didik kelas XI TBSM ini sudah menerapkan perilaku jujur dengan mengakui bahwa ia belum mengerjakan pekerjaan rumah. Walaupun mendapat teguran dan sanksi, para peserta didik tersebut memilih untuk mengakui belum mengerjakan pekerjaan rumahnya dari pada melihat jawaban milik temannya, dan mengerjakannya di pagi hari saat datang ke sekolah. Hal ini dikarenakan dalam setiap pembelajaran PPKn, guru mengajarkan bahwa kejujuran adalah yang utama. Namun masalah seperti ini harus di minimalisir agar tidak terjadi lagi, setidaknya jika hanya dilakukan sekali masih bisa di toleransi, dan jika peserta didik melakukannya lagi maka harus diberikan tindakan yang tegas.

PPKn memang mengutamakan kejujuran namun harus disertai dengan rasa tanggung jawab, mengerjakan PR merupakan tanggung jawab setiap peserta didik yang harus dipenuhi oleh peserta didik. Sebagai seorang peserta didik seharusnya sudah menyadari itu, tanpa alasan apapun peserta didik harus menyelesaikan pekerjaan rumahnya. Bahkan untuk peserta didik yang aktif di organisasi misalnya OSIS, PMR, atau ekstrakurikuler lainnya tetap harus bertanggung jawab untuk menyelesaikan 
pekerjaan rumahnya, tidak boleh menggunakan kesibukannya di organisasi sebagai alasan belum mengerjakan pekerjaan rumah.

\section{Simpulan}

Berdasarkan hasil penelitian yang telah dijelaskan diatas dapat disimpulkan bahwa pembelajaran PPKn sangat berperan dalam pembentukan karakter kejujuran peserta didik, dalam pembelajaran terdapat nilai-nilai moral baik yang bisa dicontoh oleh peserta didik. Dalam proses pembelajaran nilai-nilai tersebut juga dapat diajarkan oleh guru dangan cara tidak langsung misalnya saja dengan guru yang memberi contoh perilaku yang baik dan sesuai norma dan kaidah yang ada, dengan demikian peserta didik akan melihat dan menduplikasi perilaku tersebut. Karakter kejujuran peserta didik di SMK PGRI sangat terlihat pada saat pembelajaran dikelas maupun tingkah laku peserta didik diluar kelas. Hasil observasi dimana setiap peserta didik mengerjakan ulangan harian dan Penilaian Akhir Semester dengan usahanya sendiri tanpa mencontek dari orang lain (teman). Para peserta didik sudah menyiapkan diri dengan baik untuk Penilaian Akhir Semester setiap harinya, oleh karena itu saat ujian dimulai para peserta didik dapat mengerjakan setiap soal dengan percaya diri dan dapat menyelesaikan soal ujian dengan kemampuannya sendiri. Pada saat observasi berlangsung peserta didik diberikan pertanyaan tentang kegiatan sehari-hari dan mereka menjawab dengan jujur hal ini dapat dilihat saat peserta didik memberikan bukti bahwa jawabannya memang jujur. Beberapa kali masih ditemui peserta didik yang mengaku belum mengerjakan PR, namun sebagian peserta didik sudah menerapkan perilaku jujur dengan mengakui bahwa ia belum mengerjakan pekerjaan rumah. Dilihat dari hasil observasi tersebut dapat disimpulkan bahwa pembelajaran PPKn sangat berpengaruh dan bermanfaat dalam membentuk karakter kejujuran pada peserta didik, materi dalam pembelajaran PPKn memang memiliki pembelajaran moral yang baik bagi tumbuh kembang peserta didik. Bukan hanya karakter kejujuran saja masih banyak lagi karakter baik yang dapat ditumbuhkan melalui pembelajaran PPKn, hal ini karena materi dalam mata pelajaran tersebut mencerminkan nilai-nilai pancasila yang baik.

\section{Referensi}

Ar, Syamsyudin. (2006). Metode Penelitian Bahasa. Bandung: PT Remaja Rosdakara.

Arikunto, S. (2010). Prosedur Penelitian Suatu Pendekatan Praktek. Jakarta: Rineka Cipta.

Baswan. (2013). Meningkatkan Hasil Belajar Siswa Pada Materi Susunan Pemerintahan Daerah Melalui Metode Bermain Peran di Kelas VI SD DDI Siboang. Jurnal Kreatif Tadulako. Vol. 3, No. 3.

Corey. (1986). Belajar dan Pembelajaran. Bandung:Alpabeta.

Kesuma, D. (2012). Pendidikan Karakter Kajian Teori Dan Praktik di Sekolah. Bandung:PT. Remaja Rosdakarya.

Magdalena, I. (2020). Pembelajaran Pendidikan Kewarganegaraan di Sekolah Dasar Negeri Bojong 3 Pinang. Jurnal Pendidikan dan Sains Volume 2, Nomor 3.

Mahsun. (2017). Metode Penelitian Bahasa edisi ketiga (Tahapan, Strategi, Metode dan Tekniknya). Jakarta: Pt Raja Grafindo Persada. 
CIVICS EDUCATION AND SOCIAL SCIENSE JOURNAL (CESSJ)

Volume 3 Nomor 2 Edisi Bulan Desember 2021

Messi. (2017). Menanamkan Nilai-Nilai Kejujuran di dalam Kegiatan Madrasah Berasrama. Jurnal Manajemen, Kepemimpinan, Dan Supervisi Pendidikan. Vol 1, No. 1 Desember 2017.

Mustari, M. (2011). Nilai Karakter. Yogyakarta: Laksbang Pressindo.

Nidaul, S.A. dkk.(2021). Pengaruh Pendidikan Kewarganegaraan Dalam Membengun Karakter Generasi Muda. Jurnal Kewarganegaraan. Vol 5, No. 1 Juni (2021).

Rahayu, M. (2007). Pendidikan Kewarganegaraan Perjuangan Menghidupi Jati Diri Bangsa. Depok: PT Grasindo.

Syahrir, S. Aktualisasi Nilai-Nilai Pancasila cebagai Dasar Falsafah Negara Dan Implementasinya Dalam Pembangunan Karakter Bangsa. Jurnal Pendidikan Ilmu Social. Vol 26, No.2, Desember (2016).

Udin S. Winataputra, Dkk. (2007). Teori Belajar dan Pembelajaran. Jakarta: Universitas Terbuka.

Undang-Undang No 20 Tahun (2003) Pasal 37 Tentang Sistem Pendidikan Nasional.

Winarno. (2005). Pendidikan Kewarganegaraan. Surakarta: Universitas Sebelas Maret.

Zuriah, N. (2008). Pendidikan Moral \& Budi Pekerti dalam Perspektif Perubahan. Jakarta: Bumi Aksara. 